\title{
Microbial C-availability and organic matter decomposition in urban soils of megapolis depend on functional zoning
}

\author{
Kristina Ivashchenko ${ }^{1,2}$, Nadezhda Ananyeva ${ }^{1}$, Viacheslav Vasenev ${ }^{2}$, Sofia Sushko ${ }^{1}$, \\ Alexandra Seleznyova ${ }^{1}$ and Valeriy Kudeyarov ${ }^{1}$ \\ ${ }^{1}$ Institute of Physicochemical and Biological Problems in Soil Science of the Russian Academy of Sciences, \\ Institutskaya street\# 2, Pushchino, Moscow region, 142290, Russia \\ ${ }^{2}$ Peoples Friendship University of Russia (RUDN University), Miklukho-Maklaya street\# 6, \\ Moscow, 117198, Russia
}

\section{Abstract}

Urbanization has various strong effects on soil processes. Despite an increasing number of studies focused on soil carbon $(C)$ distribution and stocks within cities, the $C$ and nutrient availability to microorganisms and their capacity to decompose organic matter remain nearly unknown. The factors responsible for these processes in megacities are characterized by a very high spatial heterogeneity and therefore, their effects should be investigated as related to specific environmental conditions - common for urban functional zones. This study focuses on the examination of the texture, $C$, available phosphorus $(A P)$ and potassium (AK), mineral nitrogen, pH, and heavy metals (HMs) contents considering microbial C-availability (ratio of microbial biomass to $C$ ) and organic matter decomposition (BR) in soils of Moscow megapolis. The sampling sites were referred to recreational, residential and industrial zones. In the industrial and residential zones, the $p H, A K, A P$, and HMs were increased compared to recreational. Concurrently, the microbial $C$-availability and BR were much less in these zones. The high pH and AP content had negative effects on the BR for all soils. Soil segregation into groups (C-poor and $C$-rich, light texture and heavy texture) reduced heterogeneity and showed the additional patterns. In C-poor soils, the AP effect on BR was confirmed, but not of $\mathrm{pH}$. The $A K$ and $\mathrm{Cu}$ contents had negative effects on $C$-availability for $C$-poor and light soils, respectively. We conclude that careful control of the soil phosphorus and potassium contents as well as texture is necessary for planning the soil construction in megacities to consider their optimal functioning.

Keywords: Urban soil, city functional zones, microbial biomass carbon, microbial respiration, organic matter decomposition, C-availability

\section{Introduction}

Urban areas cover up to $2.0 \%$ of the global area and continue expanding by on average $16,000 \mathrm{~km}^{2}$ annually from 2000 to 2030 yrs. (Angel et al., 2011; Sharma et al., 2016). Globally, urban population has reached more than $50 \%$ and is projected to get more than $70 \%$ by 2050 (UN, 2018). Urbanization is an important pathway of global land transformation with that is responsible for considerable changes in landscapes and soil properties (Pickett et al., 2011). Urban soils are exposed to substantial anthropogenic pressures, including mechanical disturbance, soil sealing and contamination (Lehmann and Stahr, 2007). These anthropogenic pressures affect urban soil's functions and deplete their capacity to provide important ecosystem services (De Kimpe and Morel, 2000; Morel et al., 2015). Carbon (C) sequestration is widely accepted as a key soil function, which is thoroughly investigated for agricultural and natural areas (Swift, 2001; Lal, 2004), but still overlooked for urban soils (Vasenev et al, 2018). Although some recent papers reported considerable carbon stocks in urban soils (Lorenz and Lal, 2009; Vasenev and Kuzyakov, 2018) and explore the effects of urbanization on $\mathrm{C}$ stocks and $\mathrm{CO}_{2}$ fluxes (Raciti et al., 2012; Romzaykina et al., 2017), the driving factors behind these effects remain poorly known.

Soil microorganisms are the key players of $\mathrm{C}$ cycle in terrestrial ecosystems (Conrad, 1996; Cleveland and Liptzin, 2007; Kuzyakov, 2010), therefore microbial properties are widely used as relevant indicators of $\mathrm{C}$ accumulation and decomposition in soils (Nielsen and Winding, 2002; Bloem et al., 2006). In ecological studies, soil microbial biomass content and microbial indexes responsible for the soil functions (i.e., organic matter decomposition, efficiency of C-consumption and $\mathrm{CO}_{2}$-flux) are used as integral and sensitive proxies of soil health and quality (Nielsen and Winding, 2002; Fine et al., 2017). In

\footnotetext{
*Email: ananyeva@rambler.ru
} 
urban areas, microbial properties are usually studied in the context of environmental impact assessment. For example, microbial biomass and respiration were used as sensitive indicators of soil pollution by heavy metals in the cities of Aberdeen, Scotland (Yuangen et al., 2006) and Beijing, China (Zhao et al., 2013). The potential health risks of soil pathogenic microorganisms were studied in soils of several Russian cities (Marfenina and Danilogorskaya, 2017). Much less is known about the role of soil microorganisms in $\mathrm{C}$ accumulation and decomposition of organic matter in urban soils. Microbial C-availability is a relevant indicator of organic matter sustainability, which was thoroughly studied for natural and agricultural biomes (Wang et al., 2003; Bowles et al., 2014; He et al., 2018) and very rarely studied in urban soils.

Urban soils are exposed to a complex combination of environmental and anthropogenic factors, having different effects on $\mathrm{C}$ stocks and microbial properties and resulting in high heterogeneity of urban soils. For example, soil management of urban green spaces (irrigation, fertilizing, using peat and compost) lead to acceleration of the organic matter decomposition (Shchepeleva et al., 2017), whereas contamination, salinization, and over-compaction likely inhibit it. Available studies on urban soils' microbial properties lack spatial explicitness (Li et al., 2001; Matei et al., 2006; Papa et al., 2010; Shirokikh et al., 2011). Heterogeneity of urban soils requires for integral and costeffective indicators to increase the sampling density and improve understanding of the driving factors behind microbial C-availability and organic matter decomposition in a megapolis.

Moscow is among the largest megapolises of Europe. The Moscow city law (2007) on urban soils claims importance of monitoring, mapping and assessing urban soils, including quantification of their biological and microbiological properties. The information about microbial abundance and microbial respiration, as well as their spatial variability, in urban soils of Moscow is still lacking, but needed to support ecological control and decision making in urban sustainable development. This research focuses on integral and cost-effective indicators of microbial Cavailability and organic matter decomposition in the soils of Moscow megapolis. Soil microbial properties were studied in relation to chemical and physical properties and regarding urban structure - functional zoning (i.e., residential, recreational and industrial zones). The following research questions are addressed: i) In which way is soil microbial Cavailability and organic matter decomposition affected by functional zoning in the city? ii) What are the main driving factors of the microbial properties distribution in urban areas?

Soil Environ. 38(1): 31-41, 2019

\section{Materials and Methods}

\section{Study area}

Moscow city is located in the Central European part of Russia $\left(55^{\circ} \mathrm{N}, 37^{\circ} \mathrm{E}\right.$ ) and extends over $1000 \mathrm{~km}^{2}$ (survey data of 2010). Moscow has a temperate continental climate with mean annual temperature $+5.0^{\circ} \mathrm{C}$ and precipitation of $700 \mathrm{~mm}$ (weather station of Russian State Agrarian University named after K.A. Timiryazev). The city locates in sub-taiga zone where natural vegetation is dominated by coniferous and mixed forest vegetation, and Albic Retisols (WRB, 2014) are zonal soils. According to the classification of the natural landscapes, the territory covered today by Moscow city consists from three native landscape districts regarding the allocation to Moscow river: left-bank, rightbank and river-valley. These landscape districts differ in parent materials: the left-bank district is dominated by fluvioglacial sands and sandy loams, the right-bank is dominated by moraine and covering loams, whereas the river-valley distrcit is mainly formed by alluvial sands covered by loams (Stroganova et al., 1997). Soils of Moscow are very heterogeneous, varying from Technosols, strongly disturbed or artificially constructed by human activities to non-disturbed Albic Retisols, remaining in natural areas (Prokof'eva and Stroganova, 2004).

The spatial structure of the city involves units determined by the dominating land-use and land management and referred to as functional zones (i.e., residential, recreational and industrial zones). In many respects, functional zoning determines the anthropogenic impact on soils (e.g., contamination, inputs of the artificial materials and physical disturbance) and may have a strong effect on soil chemical and microbial properties (Ivashchenko et al., 2014; Sarzhanov et al., 2015). In this research, the soils of the following functional zones of Moscow were studied: recreational (urban parks, natural protected areas, boulevards and public gardens), residential (court yards) and industrial (road-sides and industries). Different subtypes of soils were observed at the studied functional zones: Technosols dominated for industrial and residential areas, whereas Albic Retisols were more typical for the less disturbed recreational areas.

Soil sampling campaign was organized in 2015 (August-October). The random stratified sampling design was implemented. In each of the three landscape districts, recreational, residential and industrial zones were chosen randomly. To decrease the heterogeneity and focus on the effect of functional zoning, the priority was given to the "nests" of the three functional zones located close to each other (around 200-1000 m distance). In total 52 sites were observed (Figure 1). At each site, a composite soil sample 
was collected from five subsamples from $2 \mathrm{~m}^{2}$ plot (center and corners) by augering with 7-cm-diameter Edelman auger for loamy sand (Eijkelkamp, the Netherlands) to a depth of 0 to $10 \mathrm{~cm}$. Soil samples were transported to the lab, air-dried $\left(22^{\circ} \mathrm{C}\right.$ ), sieved (mesh $2 \mathrm{~mm}$, roots and solid inclusions excluded), and stored no longer than 4 weeks prior to microbiological analysis (Ananyeva et al., 2008). determined by colorimetric technique $\left(0.5 \mathrm{M} \mathrm{CH} \mathrm{CH}_{3} \mathrm{COOH}\right.$ extraction, spectrophotometer, UNICO-1200, USA) and flame photometry (BWB-XP, Perfomance Plus, BWBTechnologies, Great Britain) (Arinushkina, 1970). Total heavy metals (HMs: $\mathrm{Cu}, \mathrm{Cd}, \mathrm{Ni}, \mathrm{Pb}$, and $\mathrm{Zn} ; 0.1 \mathrm{M} \mathrm{HNO}_{3}$ extraction) were determined by atomic absorption spectrophotometry (spectrophotometer S-115M1-PK, Russia) (Pawluk, 1967). The $\mathrm{pH}$ value (soil $:$ water $=1: 2.5$ )

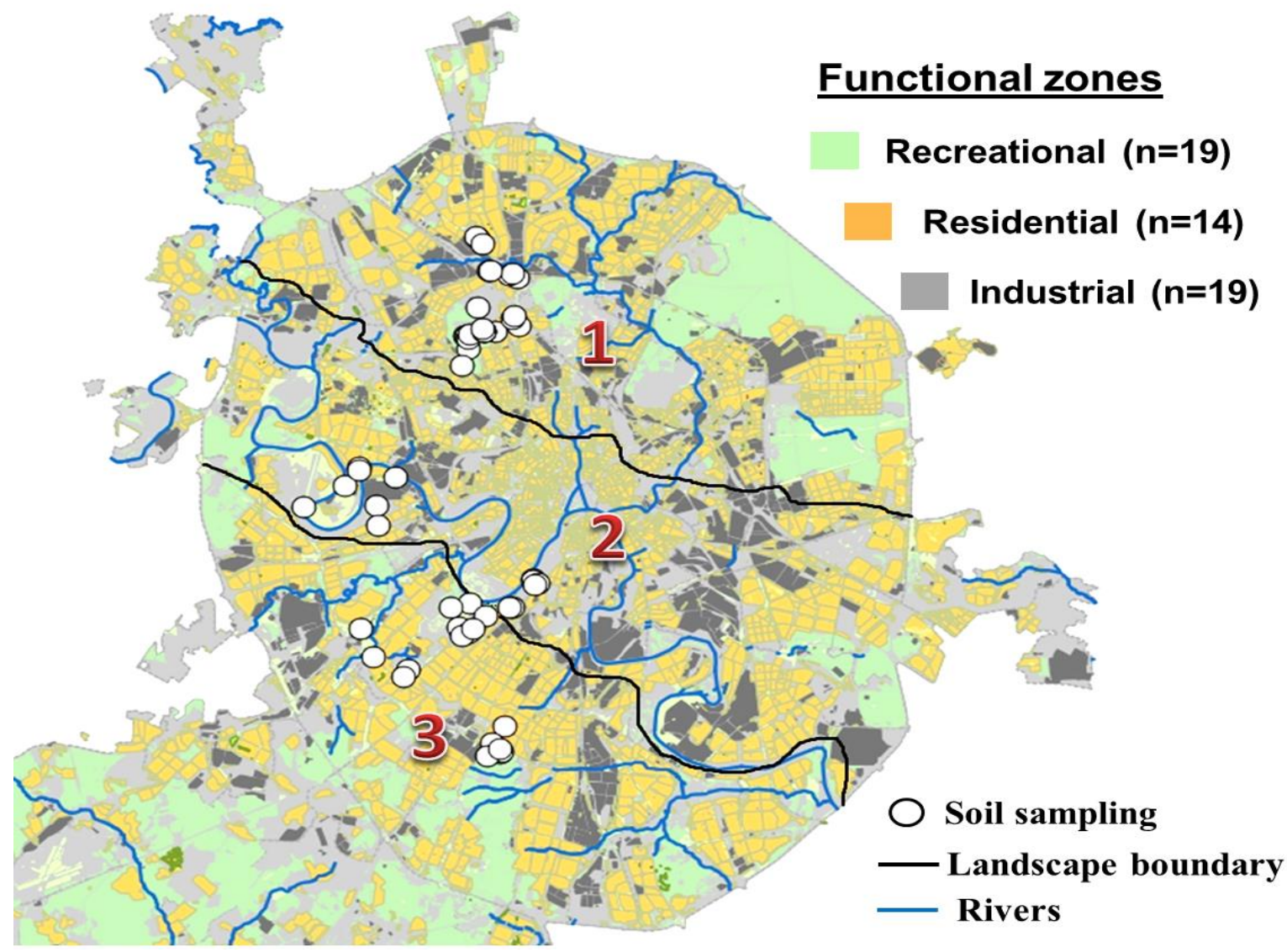

Figure 1: The distribution of soil sampling sites in left-bank (1), river-valley (2) and right-bank (3) landscapes in Moscow

\section{Soil chemical and physical analysis}

Soil organic carbon content (C) was measured by dichromate oxidation $\left(\mathrm{K}_{2} \mathrm{Cr}_{2} \mathrm{O}_{7}: \mathrm{H}_{2} \mathrm{SO}_{4}=1: 1,140^{\circ} \mathrm{C}\right)$ with subsequent titration $\left(\mathrm{FeSO}_{4} \times\left(\mathrm{NH}_{4}\right)_{2} \mathrm{SO}_{4} \times 6 \mathrm{H}_{2} \mathrm{O}\right.$ solution) (Jankauskas et al., 2006). Mineral nitrogen (N) was determined by colorimetric technique with Nessler reagent $(2 \mathrm{M} \mathrm{KCl}$ extraction) for ammonium and by using phenoldisulfonic acid $\left(0.05 \mathrm{M} \mathrm{K}_{2} \mathrm{SO}_{4}\right.$ extraction) for nitrate ions (Eastoe and Pollard, 1950; Yuen and Pollard, 1954). The $\mathrm{N}$ was calculated as sum of the nitrate and ammonium. Available phosphorus (AP) and potassium (AK) were was measured by electrochemistry (Sartorius Basic Meter PB-11, Germany). The particle size distribution was determined by the pipette method (dispersion in a sodium pyrophosphate solution) (Coates and Hulse, 1985).

\section{Soil microbiological analysis}

Soil substrate-induced respiration (SIR) was measured based on the maximal initial response of microorganisms to glucose addition (Anderson and Domsch, 1978; Ananyeva et al., 2008). Soil samples (2 g) were placed in a vial (15 $\mathrm{mL}$ volume) and $0.1 \mathrm{~mL}$ glucose solution was added dropwise (10 mg glucose $\mathrm{g}^{-1}$ soil). The vial was then tightly 
closed, and time was recorded. Soil samples with added glucose were incubated in interval from 3 to $5 \mathrm{~h}\left(22^{\circ} \mathrm{C}\right)$, and air samples were taken (time recorded) and injected into a gas chromatograph (KrystaLLyuks 4000 M, 'Meta-Chrom' manufacturer, Yoshkar-Ola, Russia) equipped with a thermal conductivity detector for measuring $\mathrm{CO}_{2}$ concentration. The rate of SIR $\left(\mu \mathrm{L} \mathrm{CO}_{2} \mathrm{~g}^{-1} \mathrm{~h}^{-1}\right)$ was used to estimate soil microbial biomass carbon ( $\mathrm{MBC}, \mu \mathrm{g} \mathrm{C} \mathrm{g}^{-1}$ ) using the following formula: $\mathrm{MBC}=\mathrm{SIR} \times 40.04+0.37$ (Anderson and Domsch, 1978). Incubation time (from 1 to 5 $\mathrm{h}$, each $0.5 \mathrm{~h}$ ) and glucose concentration $\left(2,5\right.$ and $10 \mathrm{mg} \mathrm{g}^{-1}$ soil) to achieve maximum initial respiration response for the investigated soils were based on the previous methodological research (Ananyeva et al., 2008).

Basal respiration (BR) was measured in soil samples (2 $\mathrm{g}, 24 \mathrm{~h}, 22^{\circ} \mathrm{C}$, water was added, $0.1 \mathrm{~mL} \mathrm{~g}^{-1}$ soil) to evaluate the decomposition rate of organic matter (Ananyeva et al., 2008; Anderson and Domsch, 2010). The BR was expressed as $\mu \mathrm{g} \mathrm{C}^{-1}$ soil $\mathrm{h}^{-1}$. Microbial C-availability was assessed as the ratio of $\mathrm{MBC}$ to $\mathrm{C}$ content (Anderson and Domsch, 2010). A low ratio indicates a reduced availability of organic matter to soil microorganisms (Joergensen and Emmerling, 2006; Anderson and Domsch, 2010).

Preparation of soil samples prior to microbiological analysis included adjusting up to around $55 \%$ of water holding capacity and pre-incubation (soil $\geq 150 \mathrm{~g}, 22^{\circ} \mathrm{C}, 7 \mathrm{~d}$, air exchange) to avoid an excess $\mathrm{CO}_{2}$ production after preparation procedures (Ananyeva et al., 2008; Creamer et al., 2014).

\section{Statistical analysis}

The analytical measurements were performed in four replicates per sample for the soil SIR, BR and in three replicates for chemical properties. The results were recalculated for dry soil $\left(105^{\circ} \mathrm{C}, 8 \mathrm{~h}\right)$. Normal distribution of the variables was checked by the Shapiro-Wilk test. Some soil properties (BR, C, pH, N, Cu, Pb, Cd, Ni, Zn, AP and $\mathrm{AK}$ ) were not normally distributed and were transformed for the performing statistical analysis. Spatial variation in the investigated properties was assessed by variance coefficient (CV, \%). Significance of difference in chemical and microbial properties between functional zones was tested by one-factor analysis of variance (ANOVA) and Tukey multiple comparison test. Variance homogeneity was checked by Levene's test. Relationship between chemical and microbiological soil properties was analyzed through Pearson's correlation coefficient and regression. All experimental data was statistically processed and visualized using R 3.4.3 software ( $\mathrm{R}$ Foundation for Statistical Computing, Vienna, Austria; https://www.R-project.org/).

\section{Results}

\section{Heavy metals content and nutrient status}

Although chemical properties of urban soils were highly heterogeneous (with the maximal CV values up to 52 for $137 \%$ ), some spatial patterns were clearly observed. As expected, the higher HM's contents were found in soils of the residential and industrial zones compared to recreational (Figure 2A). This outcome illustrates the increase of anthropogenic impacts from recreational to residential and industrial zones. The industrial areas were particularly polluted by $\mathrm{Pb}$ and $\mathrm{Cd}$, with those contents were, respectively, 1.8 and 1.5 times higher than in the recreational zone. The functional zones were also significantly different in $\mathrm{pH}$ with the average 6.0 in the recreational zone and 7.0 - in the residential and industrial
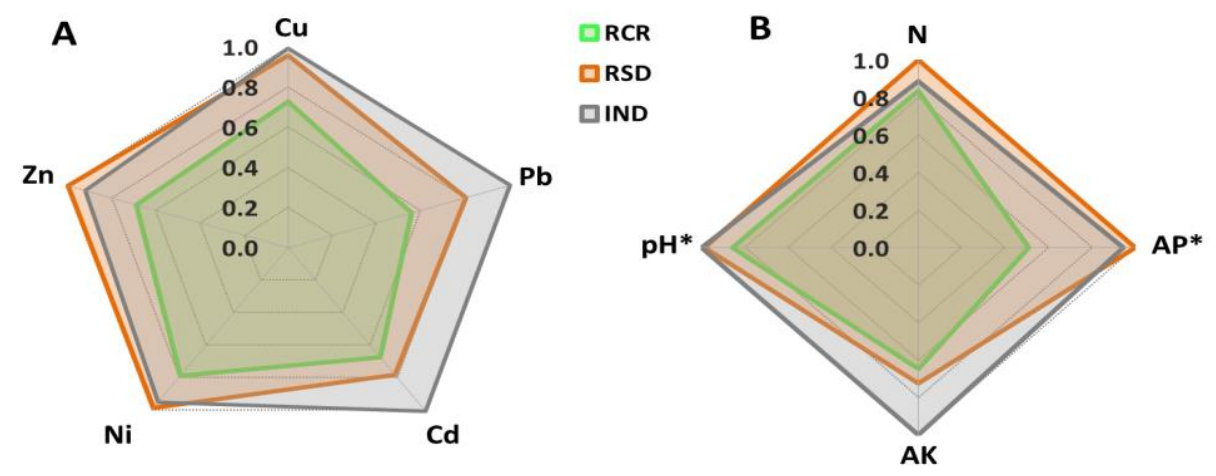

Figure 2: Heavy metals $(\mathrm{Cu}, \mathrm{Pb}, \mathrm{Cd}, \mathrm{Ni}, \mathrm{Zn})$ content $(\mathrm{A})$ and nutrients: mineral nitrogen, $\mathrm{N}$; available phosphorus, AP; available potassium, AK; and pH (B) at recreational (RCR), residential (RSD) and industrial (IND) zones in Moscow. The relative values were scaled according to 1.0 equals the highest mean of pH (7.0), nutrients and heavy metals (mg kg-1): N (24), AP (563), AK (164), Cu (37), Pb (53), Cd (0.4), Ni (17), Zn (117); *significantly difference between zones, $p<0.05$. 
zones. Phosphorous in the residential and industrial zones was almost double compared to that at the recreational (Figure 2B). The soils of Moscow megapolis were highly heterogeneous in $\mathrm{C}$ content ranged between 1.4 and $11.5 \%$ with an average of $5.0 \%$. More than half of the sites in residential (8 from 14) and industrial (13 from 19) zones contained more than $4 \%$ of soil $\mathrm{C}$ (Figure 3A), that considerably higher than in the reference Albic Retisols dominating in the region (Shishov and Voitovich, 2002). In most of the recreational zones (12 from 19 sites), C content was similar to the natural references and ranged between 1.4 and $4.0 \%$.
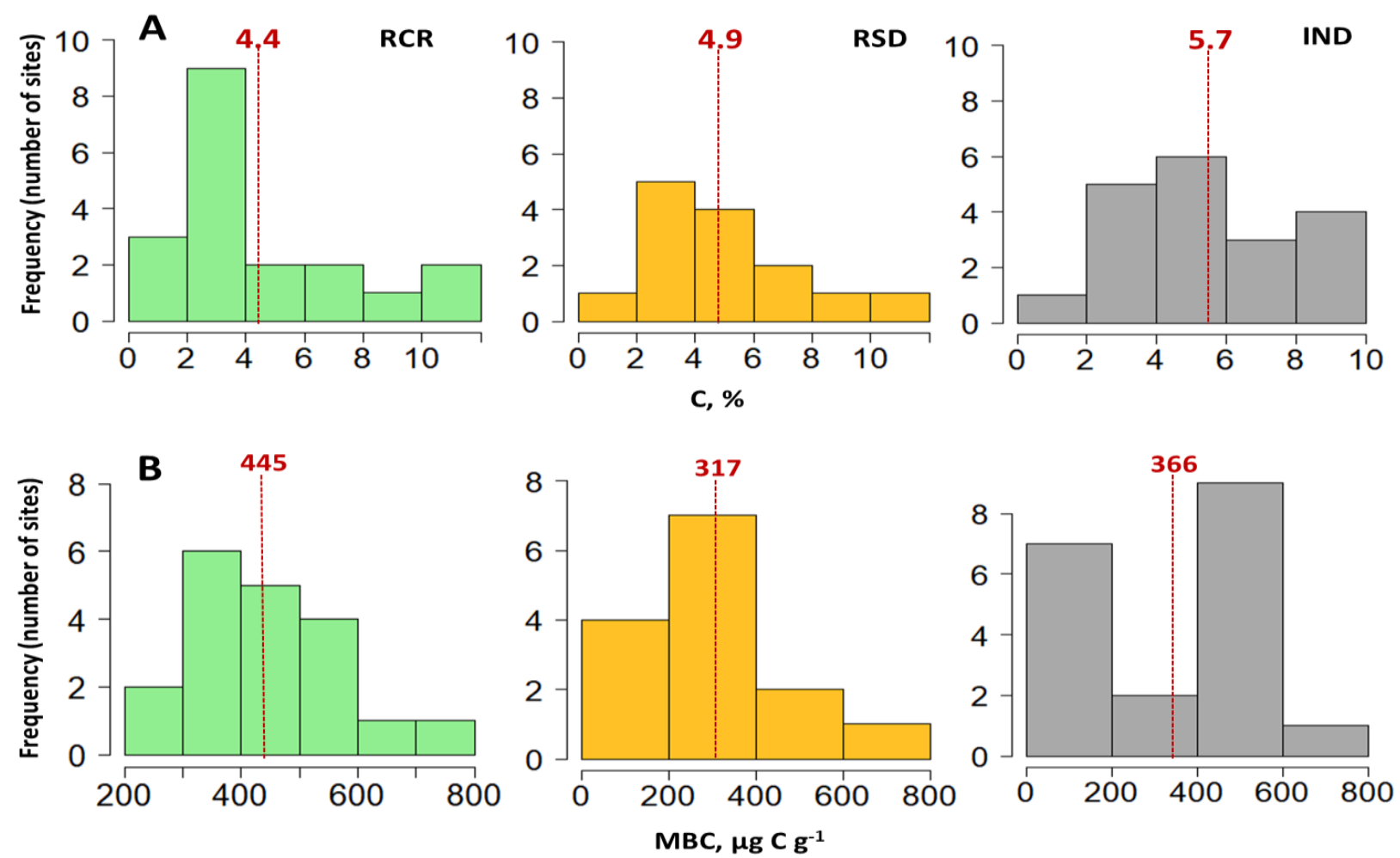

Figure 3: Soil organic carbon (A) and microbial biomass carbon (B) distribution in the soils of the recreational (RCR, $n=19)$, residential (RSD, $n=14)$ and industrial (IND, $n=19)$ zones. The red dotted line with value is mean
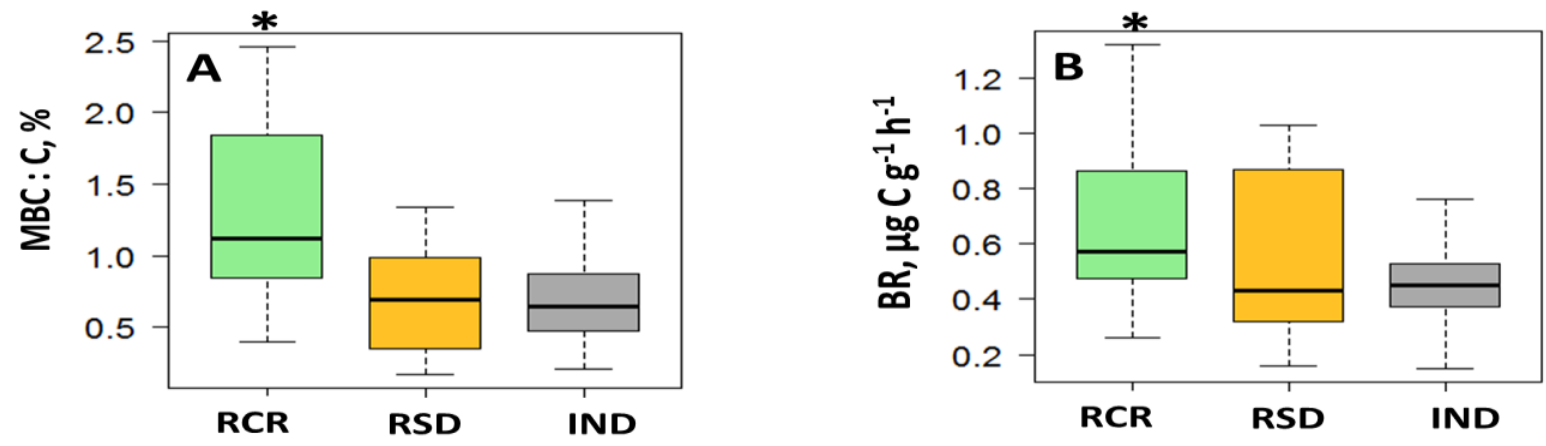

Figure 4: Ratio of microbial biomass carbon to soil organic carbon (A) and basal respiration (B) at different functional zones of Moscow (box-plot, RCR is recreational zone, $n=19$ : RSD is residential zone, n=14; IND is industrial zone, $n=19$ ); *significantly difference, $p<0.05$ 


\section{Microbial properties}

High variability was also observed in microbial properties of the urban soils in Moscow megapolis with $\mathrm{CV}$ 46, 65 and $63 \%$ for the MBC, BR and MBC:C, respectively. The effect of functional zoning on MBC was not statistically significant ( $p>0.05)$, which can be explained by high variability within the functional zones, where it ranged from 75 to $778 \mu \mathrm{g} \mathrm{C} \mathrm{g}^{-1}$. The distribution in the industrial zone was bimodal - the frequency of low and high contents was similar (Figure 3B), that illustrates the highest soil heterogeneity in the zone, where the contrast conditions stimulating, and inhibiting soil microbiota can be observed.

The highest microbial C-availability (high MBC: C ratio) was observed in the recreational zones, which was in average double compared to the industrial and residential zones (Figure 4A). Similarly, the organic matter decomposition rate (characterized by BR) was significantly lower in the residential and industrial zones, compared to the recreational (Figure 4B). Likely, this pattern follows the increase of anthropogenic pressure in industrial and recreational areas and illustrates high sensitivity of soil microbial activity to the impact.

\section{Driving factors of C-availability and organic matter decomposition rate}

Relationships between soil chemical and microbial properties. The driving factors of the microbial Cavailability (MBC: C) and organic matter decomposition rate $(\mathrm{BR})$ in urban soils of the studied functional zones were explored by analysis of the relationships with soil chemical properties. For the total dataset (without separating between the functional zones), the BR was negatively correlated with $\mathrm{pH}(\mathrm{r}=-0.46)$ and phosphorus content $(\mathrm{r}=-0.40)$. The lowest BR was observed at the sites with slightly alkaline soils ( $\mathrm{pH}$ above 7.5) and very high phosphorus content (more than $1500 \mathrm{mg} \mathrm{kg}^{-1}$ ). Both situations are very atypical for the reference zonal soils and are clearly the result of a
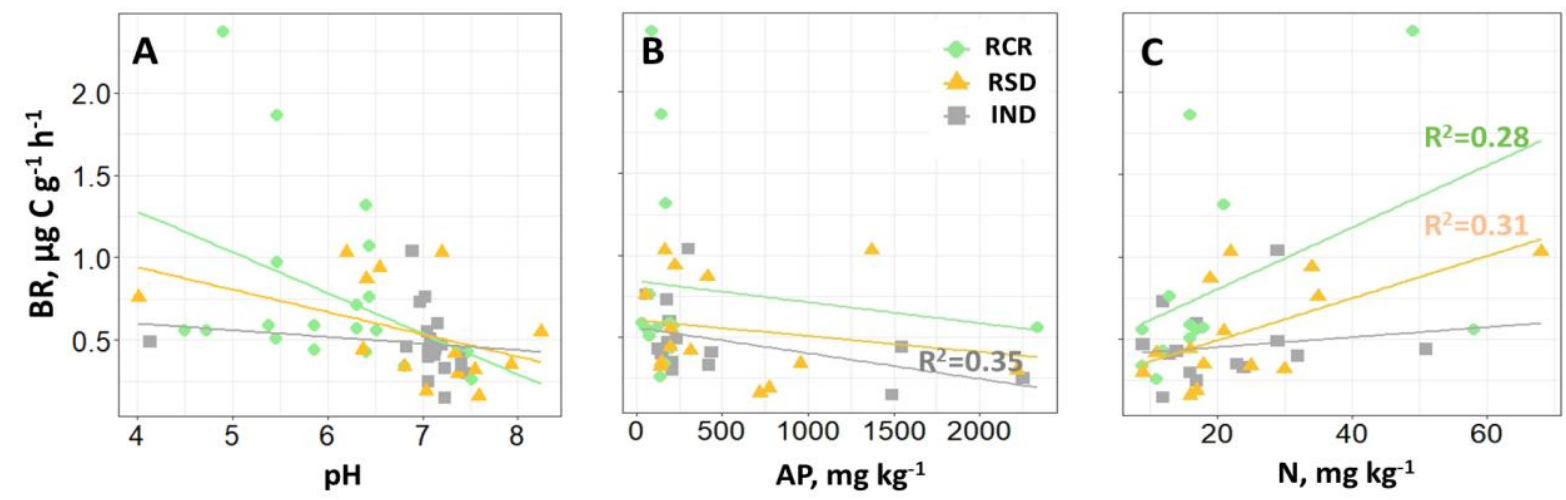

Figure 5: Relationship between basal respiration (BR) and pH (A), available phosphorus (B) and mineral nitrogen (C) for the recreational (RCR), residential (RSD) and industrial (IND) zones. The determination coefficient $\left(\mathbf{R}^{2}\right)$ isn't shown for insignificant $\beta$ (slope of the regression line) results

A

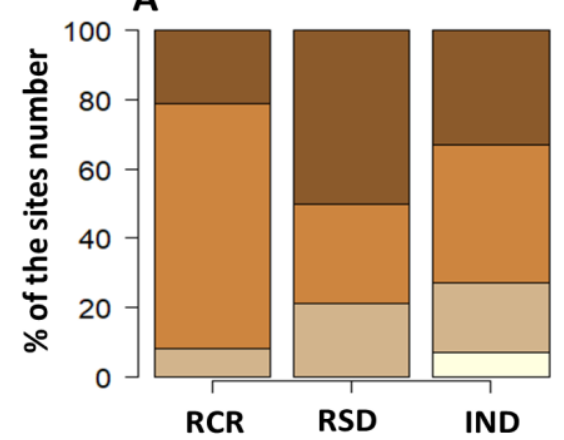

B

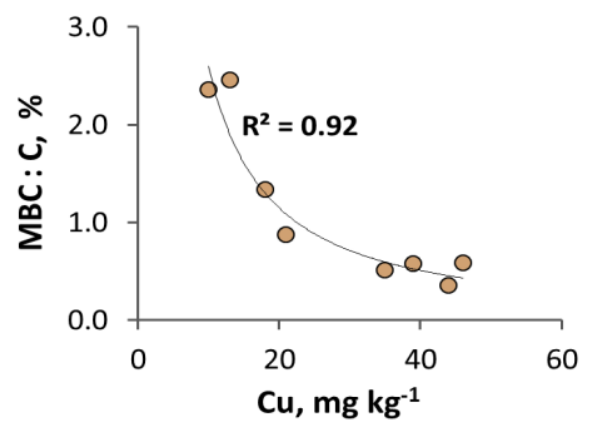

Figure 6: Composition of the texture for the soils of recreational $(R C R, n=19)$, residential $(R S D, n=14)$ and industrial (IND, $\mathrm{n}=19$ ) zones; and relationship between ratio of microbial biomass carbon (MBC) and $\mathrm{Cu}$ content within groups of $\mathrm{C}$-poor $(\leq 4 \%)$ and light texture (loamy sand + sand) urban soils 
strong anthropogenic impact. When different functional zones were analyzed separately, phosphorus and nitrogen were the factors influencing soil BR, whereas the effect of $\mathrm{pH}$ was not significant (Figure 5). Variation of BR rate within the recreational and residential zones was explained 28 and $31 \%$ by the nitrogen content, respectively. In the industrial zones, the phosphorus content has the dominating effect on the microbial activity, which was hampered by its very high contents (Figure 5).

Soil texture and microbial properties. The portion of sites with light soil texture (sandy + loamy sand) within residential $(21 \%)$ and industrial $(27 \%)$ zones was significantly higher compared to recreational (8\%) zone
(Figure 6A). To analyze the effect of soil texture on the microbial C-availability and organic matter decomposition rate, soils with light and heavy (loam and clay) texture were analyzed separately. It turned out, for the soils with light texture, microbial $\mathrm{C}$-availability (MBC: $\mathrm{C}$ ratio) was strongly negatively affected by the copper content (Figure 6B). In contrast, the effect of heavy metals on the microbial $\mathrm{C}$ availability and organic matter decomposition rate in studied soils with heavy texture was negligible $\left(\mathrm{R}^{2}=0.002-0.03\right)$.

$C$-rich and $C$-poor urban soils. Considering a very high spatial variability of the $\mathrm{C}$ content found within megapolis, we split the total sample into two parts, regarding $\mathrm{C}$ content above or below $4 \%$, which is a typical average value of $\mathrm{C}$
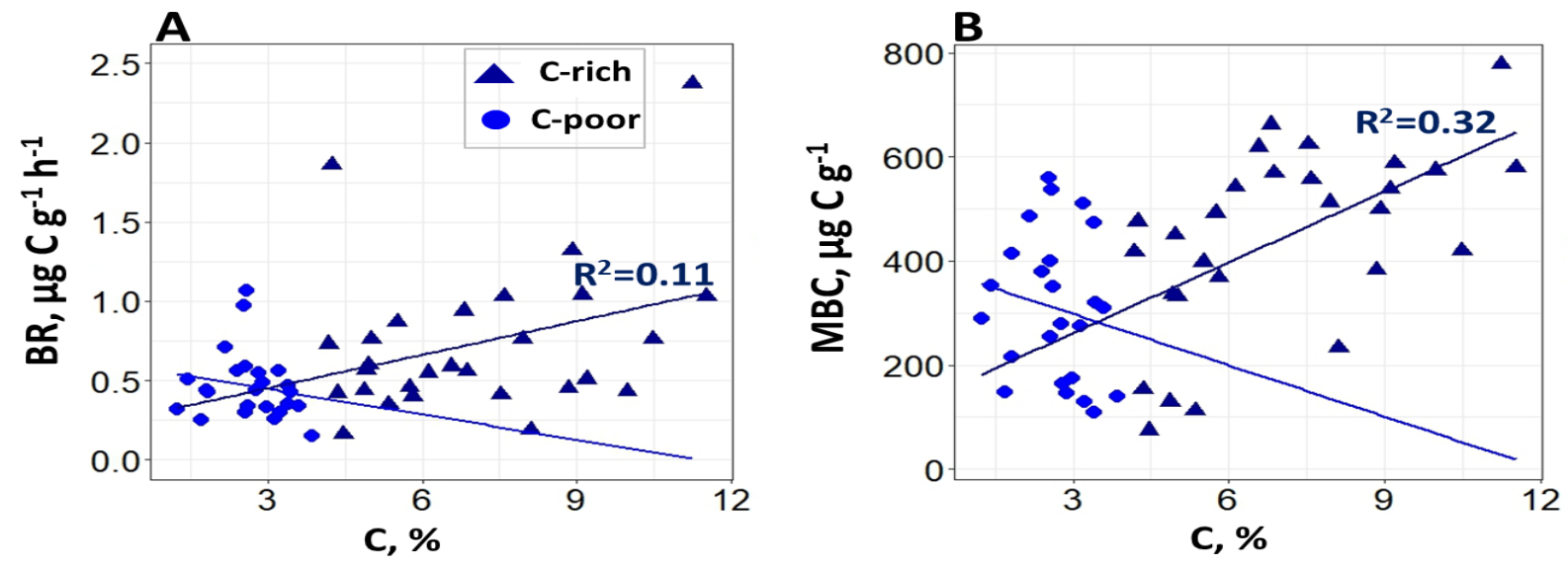

Figure 7: Relationship between organic carbon and basal respiration (A), microbial biomass carbon (B) within groups of C-rich and C-poor urban soils. The determination coefficient $\left(R^{2}\right)$ isn't shown for insignificant $\beta$ (slope of the regression line) results
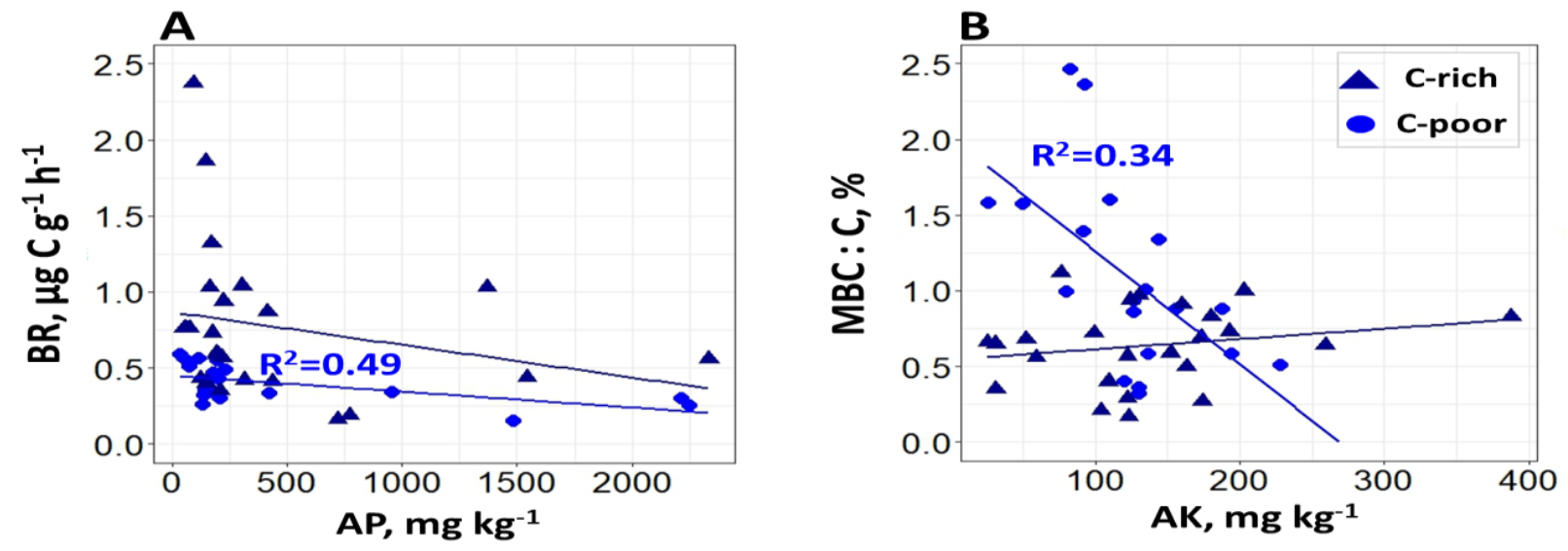

Figure 8: Relationship between basal respiration, BR and available phosphorus, AP (A); ratio of microbial biomass to organic carbon (MBC: $\mathrm{C}$ ) and available potassium, AK (B) within groups of $\mathrm{C}$-rich and $\mathrm{C}$-poor urban soils. The determination coefficient $\left(R^{2}\right)$ isn't shown for insignificant $\beta$ (slope of the regression line) results 
content in the reference Albic Retisols (Shishov and Voitovich, 2002). Urban soils, containing more than $4 \%$ of $\mathrm{C}$ (hereinafter referred to as C-rich soils) are possibly a matter of anthropic carbon additions (e.g. organic composts, sewage, turf substrates etc.) and thus are not comparable to undisturbed soils in terms of microbial properties. Soils containing less than $4 \%$ of $\mathrm{C}$ (hereinafter referred to as Cpoor soils) can be considered as comparable to natural references. Among the functional zones, almost half of industrial sites had C-rich soils, whereas just one fourth was observed in residential and recreational areas. In C-rich soils, C content had a significant effect on microbial properties and explained $11 \%$ and $32 \%$ variation of the $\mathrm{BR}$ and $\mathrm{MBC}$ (Figure 7A and 7B). In C-poor soils, the BR and MBC: $C$ was negatively affected by phosphorus and potassium contents (Figure 8), whereas the effect of $\mathrm{C}$ contents was not significant (Figure 7).

\section{Discussion}

\section{The effect of functional zoning on soil microbial properties}

The microbiological properties of urban soils might be strongly altered compared to natural analogues due to degradation of plant cover, compaction, mixing and contamination (Zhao et al., 2013; Edmondson et al., 2014; Yang and Zhang, 2015). Soil MBC and BR obtained in Moscow megapolis were on average significantly lower compared to those previously reported for natural forest soils located at the same climatic and vegetation zone (Albic Retisols, 0-10 cm, 35 sites) (Gavrilenko et al., 2011; Ivashchenko et al., 2014). Possible consequences of the urbanization effect on soil microbial properties include land conversion (Demina et al., 2018), alteration of land cover (Edmondson et al., 2014) or direct anthropogenic load (e.g., pollution and over-compaction) (Scharenbroch et al., 2005; Wang et al., 2011; Zhao et al., 2013). Complex effect of these factors and their combinations have resulted in high spatial heterogeneity of urban soils' microbial properties. Functional zoning can be considered an integral factor determining land use and management as well as type and intensity of the anthropogenic pressure. In the study, the effect of functional zoning on soil microbial features was clearly shown. The main outcome of the study was a significant decrease of $\mathrm{C}$-availability and organic matter decomposition in the residential and industrial zones compared to recreational. This outcome is in coherence with the previous studies in the cities of Beijing (Zhao et al., 2013), Kiel and Stuttgart (Beyer et al., 1995; Lorenz and Kandeler, 2005), where microbial biomass and activity in undisturbed soils (natural forest, public park, public forest) was significantly higher compared to disturbed urban soils. Apparently, an increase of anthropogenic pressure (pollution, compaction, mixing, etc.) has a negative effect on soil microbial properties, which might be critical for urban soils' functioning (Scharenbroch et al., 2005; Wang et al., 2011; Zhao et al., 2013).

\section{Driving factors of microbial C-availability and organic matter decomposition rate in urban soils}

In order to explain the significant difference in soil Cavailability and organic matter decomposition rate between the functional zones, their relationships with soil chemical features within and between the functional zones were analyzed. Soil pH, available phosphorus, potassium, and HMs contents in industrial and residential zones were considerably higher compared to the recreational (Figure 2). This pattern was opposite to the one obtained for soil microbial properties and assumed that the decrease in Cavailability and organic matter decomposition rate in the industrial zone was mainly driven by soil chemical features. Phosphorus contents had the negative effect on the rate of organic matter decomposition. The phosphorus contents in the industrial and residential zones likely has the anthropogenic origin. The problem of phosphorous pollution of urban soils is relatively novel but was already reported by several studies. For example, in Beijing phosphorous content increased from the outskirts to the city center with the highest content in the public gardens (Zhao and Xia, 2012). Organic composts, biosolids, turf substrates or fertilizers, which are commonly used for greening and urban soil construction, are the typical sources of additional phosphorous in urban soils (Zhao and Xia, 2012; Brose et al., 2016; Vidal-Beaudet et al., 2017). In the residential areas, the additional inputs of phosphorus could come from walking dogs or disposing domestic wastes. We propose that the phosphorus additions into soils could suppress the activity of the enzymes responsible for the C-cycling as it was reported by Jing et al. (2016) for the effect of triple superphosphate on soil microbiota. An alternative explanation can be that high phosphorus content in soil can decrease the root exudates production (Yoneyama et al., 2013), and be a cause of soil microbial activity reduction. The high phosphorus availability to plants increases their biomass productivity and consumption of soil mineral nitrogen, that in its turn limits available nitrogen for the microorganisms (Wang et al., 2008). Consequently, phosphorus addition causes N-limitation for microbes in producing enzymes to decompose organic matter (Jing et al., 2016). This hypothesis is confirmed by the clear positive relationship found between nitrogen content and organic matter decomposition rate obtained in Moscow soils.

Segregation of the investigated soils into groups (i.e., C-poor and C-rich, light texture and heavy texture) reduced 
heterogeneity in soil properties and showed some additional patterns. The negative effect of $\mathrm{Cu}$ on soil microbial properties was clearly shown for the light soils and was not found for the loamy soils, which buffer capacity to heavy metals is much higher. The negative effect of potassium contents on C-availability was observed for the C-poor soils. Considering that potassium fertilizers in cities could be mainly applied in the form of $\mathrm{KCl}$, the observed negative effect be indirect and explained by the $\mathrm{Cl}^{-}$ions (Pereira et al., 2019). Nevertheless, the direct effect of potassium on the microbial community is still not clearly explained in literature.

\section{Conclusions}

Microbial C-availability and organic matter decomposition are cost-effective and informative indicators of urban soils' quality and functions. These indicators are highly sensitive to environmental conditions and anthropogenic disturbance and therefore highly variable within a city. In this study, the functional zoning of the territory (the term more appropriative for urban planning) fully corresponded to the anthropogenic load, which was increasing from recreational to residential and industrial zones. In our study, we clearly demonstrated that functional zoning was the driving factors of soil microbial properties. Microbial C-availability and organic matter decomposition reduced with excessive phosphorus, potassium, and heavy metals content, these patterns were observed for residential and industrial zones. These factors had more evidence at separation the megapolis' soils on the groups (i.e. C-poor and C-rich; light and heavy soils). Following the research question of the study, we conclude that microbial properties are mainly driven by specific chemical soil properties in different functional zones, including shift in $\mathrm{pH}$ and pollution by heavy metals, potassium and phosphorous. The investigated direct and indirect effects of functional zoning on C-availability and organic matter decomposition is necessary to understand the effect of urbanization on soil microbial functions and to support decisions in urban soil monitoring and management as well as urban planning for a sustainable development.

\section{Funding}

Analysis of soil texture was carried out with financial support of the State assignment of Russian Federation, Governmental task No AAAA-A18-118013190177-9. Soil chemical properties were analyzed with the support of the RFBR project \#18-35-20052. Data processing was performed with financial the Russian Science Foundation Project \#19-77-30012.
We kindly thank Prof. Y.V. Kuzyakov for valuable recommendations regarding the results presenting.

\section{References}

Ananyeva, N.D., E.A. Susyan, O.V. Chernova and S. Wirth. 2008. Microbial respiration activities of soils from different climatic regions of European Russia. European Journal of Soil Biology 44: 147-157.

Anderson, J.P.E. and K.H. Domsch. 1978. A physiological method for the quantitative measurement of microbial biomass in soils. Soil Biology \& Biochemistry 10: 215221.

Anderson, T.H. and K.H. Domsch. 2010. Soil microbial biomass: The eco-physiological approach. Soil Biology \& Biochemistry 42: 2039-2043.

Angel, S., J. Parent, D.L. Civco, A. Blei and D. Potere. 2011. The dimensions of global urban expansion: Estimates and projections for all countries, 2000-2050. Progress in Planning 75: 53-107.

Arinushkina, E.V. 1970. Guidance for soil chemical analysis, Moscow State University named M.V. Lomonosov Press, Moscow. Russian.

Beyer, L., H.P. Blume and D.C. Elsner. 1995. Soil organic matter composition and microbial activity in urban soils. Science of the Total Environment 168: 267-278.

Bloem, J., A.J. Schouten, S.J. Sørensen, M. Rutgers, A. Van der Werf and A.M. Breure. Monitoring and evaluating soil quality. 2006. p.23-49. In: Microbiological methods for assessing soil quality. J. Bloem, D.W. Hopkins and A. Benedetti (eds.). CAB International, USA.

Bowles, T.M., V. Acosta-Martínez, F. Calderón and L.E. Jackson. 2014. Soil enzyme activities, microbial communities, and carbon and nitrogen availability in organic agroecosystems across an intensively-managed agricultural landscape. Soil Biology \& Biochemistry 68: 252-262.

Brose, D.A., L.S. Hundal, O.O. Oladeji, K. Kumar, T.C. Granato, A. Cox and Z. Abedin. 2016. Greening a steel mill slag brownfield with biosolids and sediments: A case study. Journal of Environment Quality 45: 53-61.

Cleveland, C.C. and D. Liptzin. 2007. C: N: P stoichiometry in soil: Is there a "Redfield ratio" for the microbial biomass? Biogeochemistry 85: 235-252.

Coates, G.F. and A. Carol A. 1985. A comparison of four method of size analysis of fine-grained sediments. New Zealand Journal of Geology and Geophysics 28: 369380.

Conrad, R. 1996. Soil microorganisms as controllers of atmospheric trace gases $\left(\mathrm{H}_{2}, \mathrm{CO}, \mathrm{CH}_{4}, \mathrm{OCS}, \mathrm{N}_{2} \mathrm{O}\right.$ and NO). Microbiological Reviews 60: 609-640.

Creamer, R.E., R.P.O. Schulte, D. Stone, A. Gal, P.H. Krogh, G. Lo Papa, P.J. Murray, G. Pérès, B. Foerster, M. 
Rutgers, J.P. Sousa and A. Winding. 2014. Measuring basal soil respiration across Europe: Do incubation temperature and incubation period matter? Ecological Indicators 36: 409-418.

De Kimpe, C.R. and J.-L Morel. 2000. Urban soil management: A growing concern. Soil Science 165: 3140.

Demina, S., V. Vasenev, K. Ivashchenko, N. Ananyeva, V. Plyushchikov, R. Hajiaghayeva and E. Dovletyarova. 2018. Microbial properties of urban soils with different land-use history in New Moscow. Soil Science 183: 132140.

Eastoe, J.E. and A.G. Pollard. 1950. A modified phenoldisulphonic acid method for determining nitrates in soil extracts etc. Journal of the Science of Food and Agriculture 1: 266-269.

Edmondson, J., Z. Davies, S. McCormack, K. Gaston and J. Leake. 2014. Land-cover effects on soil organic carbon stocks in a European city. Science of the Total Environment 472: 444-453.

Fine, A.K., H.M. van Es and R.R. Schindelbeck. 2017. Statistics, scoring functions, and regional analysis of a comprehensive soil health database. Soil Science Society of America Journal 81: 589-601.

Gavrilenko, E.G., E.A. Susyan, N.D. Anan'eva (Ananyeva) and O.A. Makarov. 2011. Spatial variability in the carbon of microbial biomass and microbial respiration in soils of the south of Moscow oblast. Eurasian Soil Science 44: 1125-1138.

He, Y., Y. Qi, Y. Dong, Q. Peng, S. Guo, Z. Yan, Z. Li and L. Wang. 2018. Effects of changing $\mathrm{C}$ and $\mathrm{N}$ availability on soil respiration dynamics in a temperate grassland in northern China. Geoderma 329: 20-26.

Ivashchenko, K.V., N.D. Ananyeva, V.I. Vasenev, V.N. Kudeyarov and R. Valentini. 2014. Biomass and respiration activity of soil microorganisms in anthropogenically transformed ecosystems (Moscow region). Eurasian Soil Science 47: 892-903.

Jankauskas, B., A. Slepetiene, G. Jankauskiene, M.A. Fullen and C.A. Booth. 2006. A comparative study of soil organic matter content in Lithuanian Eutric Albeluvisols and the development of transfer functions for associated analytical methodologies. Geoderma 136: 763-773.

Jing X., X.X. Yang, F. Ren, H.K. Zhou, B. Zhu and J.S. He. 2016. Neutral effect of nitrogen addition and negative effect of phosphorus addition on topsoil extracellular enzymatic activities in an alpine grassland ecosystem. Applied Soil Ecology 107:205-213.

Joergensen, R.G. and C. Emmerling. 2006. Methods for evaluating human impact on soil microorganisms based on their activity, biomass, and diversity in agricultural soils. Journal of Plant Nutrition and Soil Science 169: 295-309.

Kuzyakov, Y. 2010. Priming effects: Interactions between living and dead organic matter. Soil Biology \& Biochemistry 42:1363-1371.

Lal, R. Agricultural activities and the global carbon cycle. 2004. Nutrient cycling in agroecosystems 70: 103-116.

Lehmann, A. and K. Stahr. 2007. Nature and significance of anthropogenic urban soils. Jouurnal of Soils and Sediments 7: 247-260.

Li, X., C.S. Poon and P.S. Liu. 2001. Heavy metal contamination of urban soils and street dusts in Hong Kong. Applied Geochemistry 16: 1361-1368.

Lorenz, K. and E. Kandeler. 2005. Biochemical characterization of urban soil profiles from Stuttgart, Germany. Soil Biology \& Biochemistry 37: 1373-1385.

Lorenz, K. and R. Lal. 2009. Biogeochemical C and N cycles in urban soils. Environment International 35: 1-8.

Marfenina, O.E. and A.A. Danilogorskaya. 2017. Effect of elevated temperatures on composition and diversity of microfungal communities in natural and urban boreal soils, with emphasis on potentially pathogenic species. Pedobiologia 60: 11-19.

Matei, G.-M., S. Matei, I.G. Breabăn and R. Lăcătuşu. 2006. Microbial characteristics of urban soils from Iassy Municipium. Soil Forming Factors and Processes from the Temperate Zone 5: 63-71.

Morel, J.L., C. Chenu and K. Lorenz. 2015. Ecosystem services provided by soils of urban, industrial, traffic, mining, and military areas (SUITMAs). Journal of Soils and Sediments 8: 1659-1666.

Nielsen, M.N. and A. Winding. 2002. Microorganisms as indicators of soil health. Technical report 388. National Environmental Research Institute, Denmark. 84 p.

Papa, S., G. Bartoli, A. Pellegrino and A. Fioretto. 2010. Microbial activities and trace element contents in an urban soil. Environmental Monitoring and Assessment 165: 193-203.

Pawluk, S. 1967. Soil analyses by atomic absorption spectrophotometry. Atomic absorption Newsletter 6: 5356.

Pereira, D.G.C., I.A. Santana, M.M. Megda and M.X.V. Megda. 2019. Potassium chloride: Impacts on soil microbial activity and nitrogen mineralization. Ciência Rural, Santa Maria 49: e20180556.

Pickett, S.T.A., M.L. Cadenasso, J.M. Grove, C. Boone, P.M. Groffman, E. Irwin, S.S. Kaushal, V. Marshall, B.P. McGrath, C.H. Nilon, R.V. Pouyat, K. Szlavecz, A. Troy and P. Warren. 2011. Urban ecological systems: Scientific foundations and a decade of progress. Journal of Environmental Management 92: 331-362. 
Prokof'eva, T.V. and M.N. Stroganova. 2004. Pochvi goroda Moscva (pochvi v gorodskoi srede, ikh osobennosti i ekologicheskoe znachenie) [Soils of Moscow city (soils in urban environment, their specifics and environmental significance)]. GEOS, Moscow. Russian. 320 p.

Raciti, S.M., L.R. Hutyra, and A.C. Finzi. 2012. Depleted soil carbon and nitrogen pools beneath impervious surfaces. Environmental Pollution 164: 248-251.

Romzaykina, O.N., V.I. Vasenev, R.R. Khakimova, R. Hajiaghayeva, J.J. Stoorvogel and E.A. Dovletyarova. 2017. Spatial variability of soil properties in the urban park before and after reconstruction. Soil and Environment 36: 155-165.

Sarzhanov D.A., V.I. Vasenev, Y.L. Sotnikova, A. Tembo, I.I. Vasenev and R. Valentini. 2015. Short-term dynamics and spatial heterogeneity of $\mathrm{CO}_{2}$ emission from the soils of natural and urban ecosystems in the Central Chernozemic Region. Eurasian Soil Science 48: 416-424.

Scharenbroch, B.C., J.E. Lloyd and J.L. Johnson-Maynard. 2005. Distinguishing urban soils with physical, chemical, and biological properties. Pedobiologia 49: 283-296.

Sharma, R.C., R. Tateishi, K. Hara, S. Gharechelou and K. Iizuka. 2016. Global mapping of urban built-up areas of year 2014 by combining MODIS multispectral data with VIIRS nighttime light data. International Journal of Digital Earth 9: 1004-1020.

Shchepeleva, A.S., V.I. Vasenev, I.M. Mazirov, I.I. Vasenev, I.S. Prokhorov and D.D. Gosse. 2017. Changes of soil organic carbon stocks and $\mathrm{CO}_{2}$ emissions at the early stages of urban turf grasses' development. Urban Ecosystems 20: 309-321.

Shirokikh, I.G., T.Ya. Ashikhmina and A.A. Shirokikh. 2011. Specificity of actinomycetal complexes in urbanozems of the city of Kirov. Eurasian Soil Science 44: 180-185.

Shishov, L.L. and N.V. Voitovich. 2002. Pocvi Moskovskoi oblasti i ikh ispol'zovaniye [Soils of Moscow region and their use]. Dokuchaev Soil Science Institute, Moscow. Russian. 500 p.

Stroganova, M.N., M.G. Agarkova and A.D. Miagkova, 1997. Morphological peculiarities of soils. p. 201-211. In: Pochva, gorod, ekologiya [Soil, city, ecology]. G.V. Dobrovolskii, (ed.). Fond za economicheskuyu gramotnost, Moscow. Russian.

Swift, S. Sequestration of carbon by soil. 2001. Soil Science 166: 858-871.

United Nations. DESA/ Population division. 2018 Revision of World Urbanization Prospects. United Nations, New York.

Vasenev, V. and Y. Kuzyakov. 2018. Urban soils as hot spots of anthropogenic carbon accumulation: Review of stocks, mechanisms and driving factors. Land Degradation and Development 29: 1607-1622.

Vasenev, V.I., J.J. Stoorvogel, R. Leemans, R. Valentini and R. Hajiaghaeva. 2018. Projection of urban expansion and related changes in soil carbon stocks in the Moscow Region. Journal of Cleaner Production 170: 902-914.

Vidal-Beaudet, L., P. Cannavo, Ch. Schwartz, G. Séré, B. Béchet, M. Legret, P.-E. Peyneau, P. Bataillard, S. Coussy and O. Damas. 2017. Using wastes for fertile urban soil construction - The French Research Project SITERRE. p.159-168. In: Soils within Cities. M.J, Levin, K.H.J. Kim, J.L. Morel, W. Burghardt, P. Charzynski and R.K. Shaw (eds.). Catena Soil Science, Stuttgart.

Wang, M., B. Markert, W. Shen, W. Chen, C. Peng and Z. Ouyang. 2011. Microbial biomass carbon and enzyme activities of urban soils in Beijing. Environmental Science and Pollution Research 18: 958-967.

Wang, Q.K., S.L. Wang and Y.X. Liu. 2008. Responses to N and $\mathrm{P}$ fertilization in a young Eucalyptus dunnii plantation: Microbial properties, enzyme activities and dissolved organic matter. Applied Soil Ecology 40: 484490.

Wang, W.J., R.C. Dalal, P.W. Moody and C.J. Smith. 2003. Relationships of soil respiration to microbial biomass, substrate availability and clay content. Soil Biology \& Biochemistry 35: 273-284.

WRB. World reference base for soil resources. 2014. FAO, Rome.

Yang, J-L and G-L. Zhang. 2015. Formation, characteristics and eco-environmental implications of urban soils - A review. Soil Science and Plant Nutrition 61: 30-46.

Yoneyama, K., X. Xie, T. Kisugi, T. Nomura and K. Yoneyama. 2013. Nitrogen and phosphorus fertilization negatively affects strigolactone production and exudation in sorghum. Planta 238: 885-894.

Yuangen, Y., C.D. Campbell, L. Clark, C.M. Cameron and E. Paterson. 2006. Microbial indicators of heavy metal contamination in urban and rural soils. Chemosphere 63: 1942-1952.

Yuen S.H. and A.G. Pollard. 1954. Determination of nitrogen in agricultural materials by the nessler reagent. II. Micro-determinations in Plant Tissue and in Soil Extracts. Journal of the Science of Food and Agriculture 5: 364 - 369.

Zhao, D, F. Li, Q. Yang, R. Wang, Y. Song and Y. Tao. 2013. The influence of different types of urban land use on soil microbial biomass and functional diversity in Beijing, China. Soil Use and Management 29: 230-239.

Zhao, X. and Xia X. 2012. Total nitrogen and total phosphorous in urban soils used for different purposes in Beijing, China. Environmental Sciences 13: 95-104. 